\title{
Climate change and the future of endemic flora in the South Western Alps: relationships between niche properties and extinction risk
}

\author{
Davide Dagnino $^{1}$ (D) $\cdot$ Maria Guerrina $^{1} \cdot$ Luigi Minuto $^{1} \cdot$ Mauro Giorgio Mariotti $^{1} \cdot$ Frédéric Médail $^{2} \cdot$ Gabriele Casazza $^{2}$
}

Received: 12 February 2020 / Accepted: 3 October 2020 / Published online: 16 October 2020

(C) The Author(s) 2020

\begin{abstract}
Climate change seriously threatens biodiversity, particularly in mountain ecosystems. However, studies on climate change effects rarely consider endemic species and their niche properties. Using species distribution models, we assessed the impact of climate change on the endemic flora of the richest centre of endemism in the Alps: the South-Western Alps. We projected the potential distributions of 100 taxa under both an optimistic (RCP2.6) and a pessimistic (RCP8.5) climate scenario, analysing the relationships between range dynamics and several predictors (dispersal abilities, vegetation belts, niche marginality, niche breadth, altitudinal range and present range). The negative impact ranged from weak to severe according to the scenario, but the extinction risk was low. The dispersal abilities of species strongly affected these range dynamics. Colline and subalpine species were the most threatened and the relationship between range dynamics and predictors varied among vegetation belts. Our results suggest that the rough topography of the SW Alps will probably buffer the climate change effects on endemics, especially if climate will remain within the limits already experienced by species during the Holocene. The presence of the Mediterranean-mountain flora, less affected by climate change than the alpine one, may explain the lower number of species threatened by extinction in the SW Alps than in other European mountains. These results suggest that the relationship between plants' sensitivity to climate change, and both niche properties and vegetation belts, depends on the difference between the current climate in which species grow and the future climate, and not just on their niche breadth.
\end{abstract}

Keywords Biodiversity hotspot $\cdot$ Ecological niche $\cdot$ Endemic species $\cdot$ Global warming $\cdot$ Species distribution model $\cdot$ Vegetation belt

Communicated by Christopher Reyer

Electronic supplementary material The online version of this article (https://doi.org/10.1007/s10113-020-01708-4) contains supplementary material, which is available to authorized users.

Davide Dagnino

dagnino.botanica@gmail.com

Maria Guerrina

maria.guerrina@edu.unige.it

Luigi Minuto

luigi.minuto@unige.it

Mauro Giorgio Mariotti

m.mariotti@unige.it

Frédéric Médail

frederic.medail@imbe.fr
Gabriele Casazza

gabriele.casazza@unige.it

1 Dipartimento di Scienze della Terra, dell'Ambiente e della Vita (DISTAV), Università di Genova, Corso Europa 26,

I-16132 Genoa, Italy

2 Institut Méditerranéen de Biodiversité et d'Ecologie marine et continentale (IMBE), Aix Marseille Université, Avignon Université, CNRS, IRD. Campus Aix, Technopôle de l'Environnement Arbois-Méditerranée, BP 80, F-13545 Aix-en-Provence cedex 4, France 


\section{Introduction}

It is widely accepted that global warming is inducing one of the greatest threats to biodiversity (Thomas et al. 2004; Bellard et al. 2012; Cahill et al. 2012; Moritz and Agudo 2013; Sax et al. 2013). In particular, mountain ecosystems are important centres of biodiversity where species and ecosystems at risk persist (Nogués-Bravo et al. 2007; Hoorn et al. 2018) and are particularly exposed to climate change effects, even if their vulnerability is highly variable among mountain systems (Engler et al. 2011). In Europe, the strongest effects of climate change are projected in Southern European mountain systems, where the increase of temperature will be associated with a decrease of precipitation (Thuiller et al. 2005a; Engler et al. 2011; Pauli et al. 2012) and a severe reduction or disappearance of permanent snow and ice (Huss et al. 2017).

Studies aiming to provide an overview of the effect of climate change on mountain species have mainly addressed widely distributed taxa while the few available overview studies focusing on endemic species have taken into account an array of different endemics and not mainly mountain ones (e.g. Thuiller et al. 2006; Loarie et al. 2008; Casazza et al. 2014). Studies investigating the mountain endemics have focused on a small number of species (e.g. Cotto et al. 2017) or on ecologically specialized taxa (e.g. Dirnböck et al. 2011). Therefore, we still lack a general understanding of the effect of future climate change on mountain endemic species.

Endemic mountain plants are expected to be more susceptible to habitat modification induced by climate change (Dirnböck et al. 2011; Dullinger et al. 2012) because they are thought to have a narrow ecological niche, occurring in narrow areas and in specific habitats (Essl et al. 2009). The poor dispersal ability of most of these species affected their current distribution not enabling them to keep pace with past climate change (Essl et al. 2011) and it will probably prevent them to keep up with future ones (Malcolm et al. 2002; Engler et al. 2009; Ozinga et al. 2009). For these reasons, estimating the future distribution range of endemic mountain plants is currently a primary task to support the development of proactive strategies to mitigate the negative impacts of climate change on biodiversity by conservation biologists and decision-makers (Pereira et al. 2010; Parmesan et al. 2011).

The South Western Alps (hereafter SW Alps), located at the interface of the Mediterranean Basin and the Alps, are one of the most relevant biogeographical areas in Europe because of the high number of endemic taxa. In fact, the SW Alps are the richest centre of endemism in the Alps (Aeschimann et al. 2011) and one of the most important biodiversity hotspots of the Mediterranean Basin (Médail and Quézel 1997). The high biodiversity of this area is primarily the result of the close proximity of the Mediterranean and Alpine climates, the high habitat heterogeneity and the complex biogeographical history (Casazza et al. 2005, 2008; Fauquette et al. 2018).
Unfortunately, the SW Alps are also one of the European mountain systems that likely will be more prone to climate change (Engler et al. 2011).

In this study, we used species distribution models (SDMs; Guisan and Zimmermann 2000) to analyse the potential effects of climate change on 100 plants endemic or sub-endemic to the SW Alps under different climate change scenarios, considering their dispersal abilities. We analysed the potential range changes and the risk of species extinction taking into account the vegetation belts where the species grow. Moreover, as the ecological characteristics of species can affect their sensitivity to climate change (Thuiller et al. 2005b), we explored the relationships between potential range loss and niche properties (i.e. niche marginality, niche breadth, altitudinal range and current potential range).

\section{Methods}

\section{Study area and taxa}

The study area includes the SW Alps (Marazzi 2005) and surrounding areas for a total of about $160,000 \mathrm{~km}^{2}$ (Online Resource 1), in order to cover the entire distributional range of sub-endemic taxa (i.e. taxa in which at least the $75 \%$ of the populations occur in the SW Alps). In the last two centuries, many floristic surveys investigated the study area, providing an extensive documentation about the distribution of endemic species. The occurrence dataset was obtained from regional databases, herbaria, literature and personal observation made by the authors or expert botanists (Online Resource 2). We did not take into account those taxa having nomenclatural problems, showing uncertainties or lacks in distributional data, or occurring in peculiar and azonal habitats like dripping and springs (for a detailed description of the selection procedure, see Online Resource 2). To mitigate pseudo-replication of occurrences and to harmonize the occurrence dataset to the climatic layers (see below), we retained for each species only one occurrence per grid cell of about $1 \times 1 \mathrm{~km}$ spatial resolution. Furthermore, we excluded taxa having an area of occupancy lower than $25 \mathrm{~km}^{2}$, in order to assure that species occur in at least 25 grid cells, which is the minimum sample size suggested by van Proosdij et al. (2016) for widespread species (Online Resource 2). Overall, we selected 68 endemic and 32 sub-endemic taxa, representing $56 \%$ and $80 \%$ of the endemic and sub-endemic flora of the SW Alps, respectively. The final data set consisted of 34,069 occurrences, ranging from 27 to 1805 occurrences per species (Online Resource 2).

To analyse the potential impact of climate change per vegetation belt, the study area was subdivided into three main vegetation belts (i.e. colline, montane and subalpine), according to Engler et al. (2011). Each species was assigned to the vegetation belt with the highest frequency of occurrences (Online Resource 2). 


\section{Environmental layers}

We downloaded the monthly values of precipitation, maximum and minimum temperature for both current (i.e. 1979-2013) and future (i.e. 2061-2080; hereafter 2070) time slices at about $1 \times$ $1 \mathrm{~km}$ spatial resolution from CHELSA v.1.2 dataset (Karger et al. 2017a, 2017b; www.chelsa-climate.org). For the future climate, we chose two representative concentration pathways (RCPs) representing optimistic and pessimistic possible future emission trajectories and coded according to a possible range of radiative forcing values in the year 2100 relative to preindustrial values $\left(+2.6\right.$ and $+8.5 \mathrm{~W} / \mathrm{m}^{2}$, hereafter optimistic and pessimistic scenarios, respectively; Intergovernmental Panel on Climate Change, 2014). We used RCP projections from five general circulation models (GCMs), which represent physical processes in the atmosphere, ocean, cryosphere and land surface. According to Sanderson et al. (2015), we selected five noninterdependent GCMs: CESm1-CAM5, FIO-ESM, IPSLCM5A-MR, MIROC5 and MPI-ESM-MR. We calculated nineteen bioclimatic variables (Online Resource 3) for both current and future time slices using the "dismo" package (Hijmans et al.
2017) implemented in $R$ (R Core team 2017). Following the approach of Hamann et al. (2015) and Maiorano et al. (2012), we used the first two axes of a principal component analysis (PCA) as environmental variables for species distribution modelling to assure the model's transferability (i.e. the predictive success of SDMs calibrated in one spatiotemporal range and projected onto another one; Petitpierre et al. 2017). The PCA was calculated on the bioclimatic variables for current and for each future scenario (i.e. all the combinations of RCPs and GCMs) pooled together; then the values of the first two axes of the PCA of each climate were separated to obtain one data set for the current and five data sets for each of future scenarios (Fig. 1). The PCA was performed using the R package "ade4" (Dray and Dufour 2007).

\section{Species distribution models}

To account for model-based uncertainties in the modelling process (Araújo and New 2007; Petchey et al. 2015), five widely used SDM techniques implemented in the R package BIOMOD2 v 3.3.7 (Thuiller et al. 2009) were used (Fig.
Fig. 1 Environmental layers and model settings. Representative concentration pathways (RCPs) and general circulation models (GCMs) were obtained from CHELSA v.1.2 dataset (Karger et al. 2017a, 2017b; www.chelsaclimate.org). Model techniques: CTA, classification tree analysis; GBM, generalised boosted models; GLM, generalized linear models; MARS, multivariate adaptive regression splines; RF, random forest

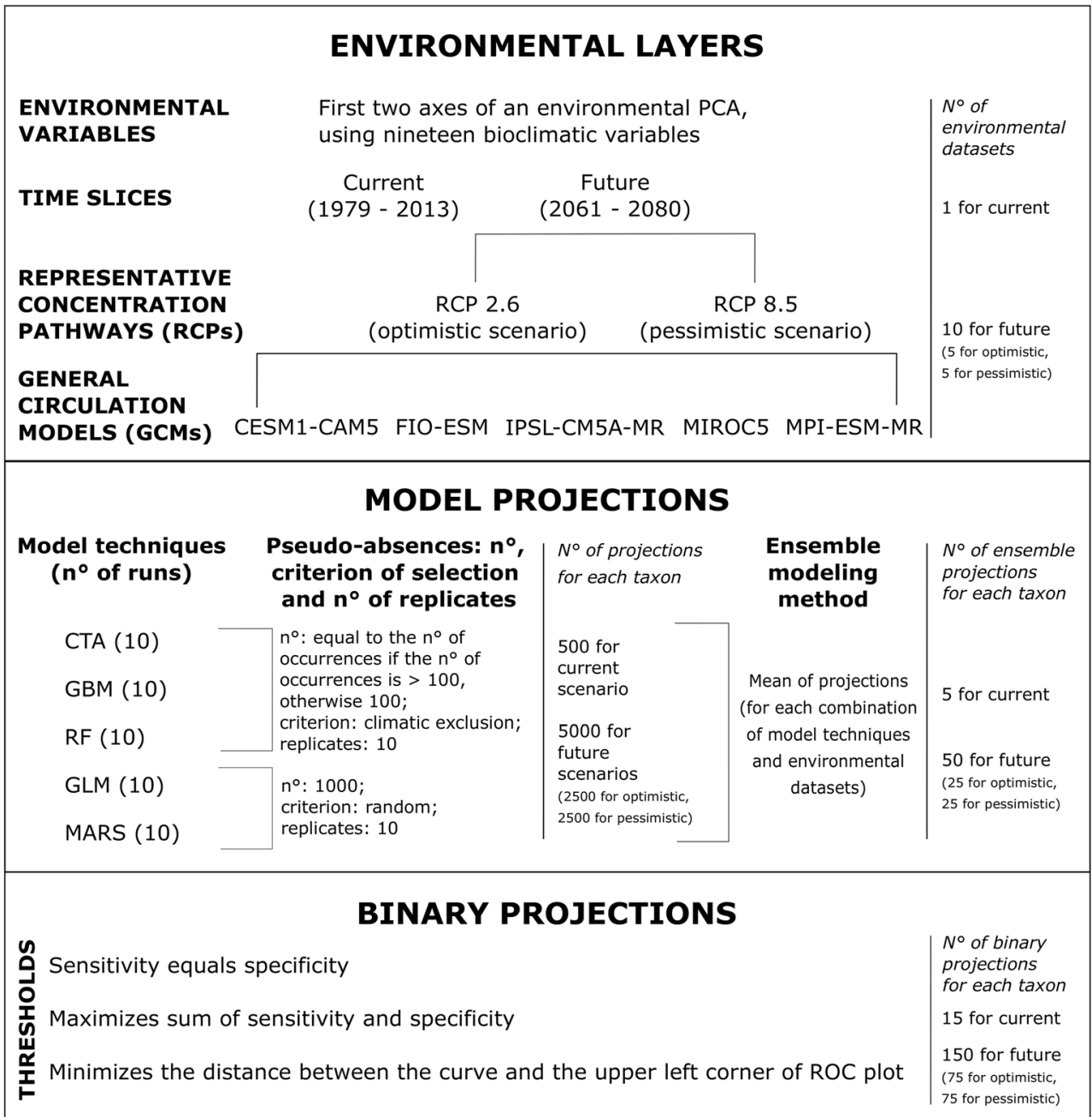


1). These modelling techniques belong to three different model classes, i.e. two machine learning methods (generalised boosted models - GBM, Ridgeway 1999, and random forest-RF, Breiman 2001), two regression methods (generalized linear models-GLM, McCullagh and Nelder 1989, and multivariate adaptive regression splinesMARS, Friedman 1991) and one classification method (classification tree analysis-CTA, Breiman et al. 1984). According to Barbet-Massin et al. (2012), ten replicate sets of pseudo-absences were generated for each taxon. For each pseudo-absence set, a split-sample cross-validation was repeated 10 times, using a random subset $(30 \%)$ of the initial data set (Fig. 1). Model performance was evaluated using two different measures implemented in BIOMOD2: the area under the curve of a ROC plot (Hanley and McNeil 1982) and the true skill statistic (Allouche et al. 2006). The area under the curve of a ROC plot is obtained plotting the proportion of true positives against the proportion of false positives and it is equivalent to the probability that the model will rank a presence site higher than an absence site. True skill statistic is the success rate of prediction both for presence and absence sites. Both measures are less affected by prevalence and are considered highly effective measures for the performance of ordinal score models (Liu et al. 2005; Allouche et al. 2006). Projections from different model techniques and environmental datasets were averaged to implement an ensemble forecasting approach (Marmion et al. 2009), obtaining 5 current and 50 future projections (Fig. 1). To assess uncertainty in the model projections, we calculated the standard deviation among projections per grid cells for each modelling technique. Then we calculated the average standard deviation for each species and climate. Finally, we converted the continuous suitability maps into binary projections of species presence and absence (Fig. 1) using three different thresholds, implemented in the R package "PresenceAbsence" (Freeman and Moisen 2008). We used three different thresholds, which perform equally or better than others (Liu et al. 2005; Cao et al. 2013), because the choice of threshold may affect projection bias. Species were then considered occurring in a cell if at least $50 \%$ of models projected its occurrence there (i.e. a majority consensus rule).

\section{Spatial indices for distribution under future climates and dispersal scenario}

The percentage of projected future range change $(\mathrm{RC})$ was estimated using the formula $\mathrm{RC}=100 \times(\mathrm{RG}-\mathrm{RL}) / \mathrm{PR}$, where range gain $(R G)$ is the number of grid cells projected to be not suitable under current climate but suitable under future climate, range loss (RL) is the number of grid cells projected to be suitable under current climate but unsuitable under future climate and present range (PR) is the number of grid cells projected to be suitable under the current climate. A positive $\mathrm{RC}$ value indicates an expected increase in range size, while a negative value indicates an expected decrease in range size. Species with a percentage of RC ranging from 80 to -100 were considered at high risk of extinction. To avoid that climatically suitable areas where species currently do not occur might affect the analyses, the calculation of PR was restricted to grid cells which are no more than $5 \mathrm{~km}$ away from species occurrences.

The dispersal ability of species plays a key role in projecting the effects of climate change on species distribution, because it affects their capability to track the geographical shift in suitable environments (Malcolm et al. 2002). For this reason, we assigned each species to a dispersal category, according to the classification of Vittoz and Engler (2007), which is based on dispersal vector and plant traits and does not take into account rare and stochastic long-distance dispersal events. To obtain the maximum distance that each species could reach in the investigated time interval, the upper limit of the distance within which $99 \%$ of seeds of each species are dispersed was multiplied for 55 years (Online Resource 2 ). Then, for both scenarios, the spatial indices were calculated in a buffer zone calibrated on the dispersal ability of the species around the grid cells that were used to calculate PR values.

\section{Predictors of range loss and change}

The relationship between predictors of range dynamics and both RL and RC was evaluated by using a multiple linear regression model. Models were built by considering vegetation belts and the interactions between the single predictors and the vegetation belts as main effects. As predictors, we considered niche properties like niche marginality and breadth (sensu Dolédec et al. 2000), altitudinal range and PR (i.e. the number of currently suitable cells). Moreover, we used dispersal distance as a predictor of RC. Niche marginality was calculated using the OMI index, which is the distance between the mean environmental conditions (in our study the 19 bioclimatic variables) used by the species and the mean environmental conditions of the study area. Niche breadth was calculated using the tolerance index, which is the variance of habitat conditions used by the species. The altitudinal range was calculated as the standard deviation of the altitude of species occurrences and it could be considered a proxy of niche breadth (Essl et al. 2009).

\section{Results}

Model evaluation under current climatic conditions indicated a good model performance for the majority of modelling 
techniques and species (Online Resource 4). Similarly, the uncertainty in the model projection was mainly low for all species and it was slightly higher in the pessimistic than in the optimistic scenario (Online Resources 4). Considering all species together, we found differences between the two future scenarios in range loss and change. In particular, the loss was low and the change was slightly negative (i.e. from 0 to $-20 \%$ for the majority of species) under the optimistic scenario, while the loss was high and the change was strongly negative (i.e. from -60 to $-80 \%$ for the majority of species) under the pessimistic scenario (Fig. 2; Online Resource 5). Therefore, we projected a high extinction risk (i.e. range change from -80 to $-100 \%$ ) for $14 \%$ of species under the pessimistic scenario only. In contrast to loss and change, the gain was always low under both scenarios (i.e. from 0 to $10 \%$ for the majority of species), with the exception of few species (e.g. Prunus brigantina Vill., Asplenium jahandiezii (Litard.) Rouy, Ophrys bertolonii Moretti subsp. saratoi (E.G.Camus) R.Soca, Centaurea jordaniana Godr. \& Gren., Helictotrichon setaceum (Vill.) Henrard) which showed a very high gain (i.e., more than doubling their range), resulting in an overall positive change under both scenarios (Fig. 2; Online Resource 5).

We did not detect any difference among the three vegetation belts in range loss, change and gain under the optimistic scenario (Fig. 2; Online Resource 5). Conversely, under the pessimistic scenario, mountain species showed slightly lower loss and slightly lower negative change than colline and subalpine species, while the gain was not different among vegetation belts. In addition, the species with high extinction risk belong mainly to colline and subalpine belts (i.e. colline $=$ $16 \%$; montane $=3.8 \%$; subalpine $=18.3 \%$ ) .

Under the optimistic scenario, range loss was significantly positively related to niche breadth and significantly negatively related to altitudinal range and current potential range in colline species (Fig. 3; Online Resource 6). Under the pessimistic scenario, range loss was significantly negatively related to niche marginality, altitudinal range and current potential range in colline species, to altitudinal range in mountain species and to the altitudinal range and current potential range in subalpine species, while it was significantly positively related to niche marginality in subalpine species (Fig. 3; Online Resource 6). Under the optimistic scenario, range change was significantly negatively related to current potential range in colline and mountain species and significantly positively related to dispersal distance in colline, mountain and subalpine species (Fig. 4; Online Resource 6). Under the pessimistic scenario, range change was significantly negatively related to current potential range in mountain species, significantly positively related to altitudinal range in mountain species and significantly positively related to dispersal distance in colline, mountain and subalpine species (Fig. 4; Online Resource 6).

\section{Discussion}

\section{Future impacts of climate change on the distribution of endemic plants}

In this study on the effect of climate change on 100 endemic species in the SW Alps, we showed that if the climate change stays within the limits already experienced by species during the Holocene (as projected under the optimistic scenario- Guiot and Cramer 2016; Fauquette et al. 2018), the range loss will be moderate. Moreover, our study showed that plants' sensitivity to climate change mainly depends on the difference between the current climate where species grow and the projected climate.

The negative effect of climate change on the potential distribution recorded in the majority of species ( $79 \%$ and $93 \%$ of species under an optimistic and pessimistic scenario, respectively; Fig. 2, Online Resource 5) is in line with other studies on plants endemic to other biogeographical regions (Centralnorthern Mediterranean region: Casazza et al. 2014; California: Loarie et al. 2008; South Africa: Thuiller et al. 2006) and with studies on widely distributed plants of the main European mountain chains (Thuiller et al. 2005a; Engler et al. 2011; Pauli et al. 2012). Different from most of these studies, in most species, we projected a small range gain that will not mitigate the RL (Fig. 2, Online Resource 5). This inconsistency may depend on the use of different dispersal scenarios (unlimited dispersal vs. limited dispersal scenario). In fact, the unlimited dispersal scenario assumes that a species can colonize all locations without physiological, environmental or geographical limitations, probably overestimating the $R G$ for species whose suitable habitat is projected to increase (Engler et al. 2009). However, even if our approach attempts to provide a plausible estimate of the maximum distance that species can cover until 2070, it does not take into account all factors affecting dispersion. Most of the SW Alps endemics have a low dispersal ability (Online Resource 2), primarily limited by the absence of specialized diaspores for wind or bird dispersal, and by the short stem height. Therefore, during the investigated time interval, the majority of the studied species (i.e. the $67 \%$ of species) probably will be not able to move from the grid cells where they currently occur (i.e. dispersion lower than $500 \mathrm{~m}$ in 55 years), like in a no-dispersal scenario. Nevertheless, in accordance with the idea that the intensity of the climate warming may affect the distance that the species has to cover to maintain constant climate conditions (Kuussaari et al. 2009), we detected a higher RG under the optimistic than under the pessimistic scenario (Fig. 2, Online Resource 5). Moreover, the high environmental heterogeneity in mountain areas like the SW Alps might further shorten this distance (Engler et al. 2009; Loarie et al. 2009; Sandel et al. 2011), enabling also species with poor dispersal ability to keep up with the shift to suitable climatic conditions under the optimistic scenario. 
Fig. 2 Results of range analysis under optimistic (i.e. RCP 2.6) and pessimistic (i.e. RCP 8.5) scenarios for studied taxa belonging to each vegetation belt. $\mathrm{C}$, colline; $\mathrm{M}$, montane; $\mathrm{S}$, subalpine

\section{OPTIMISTIC SCENARIO (RCP2.6)}
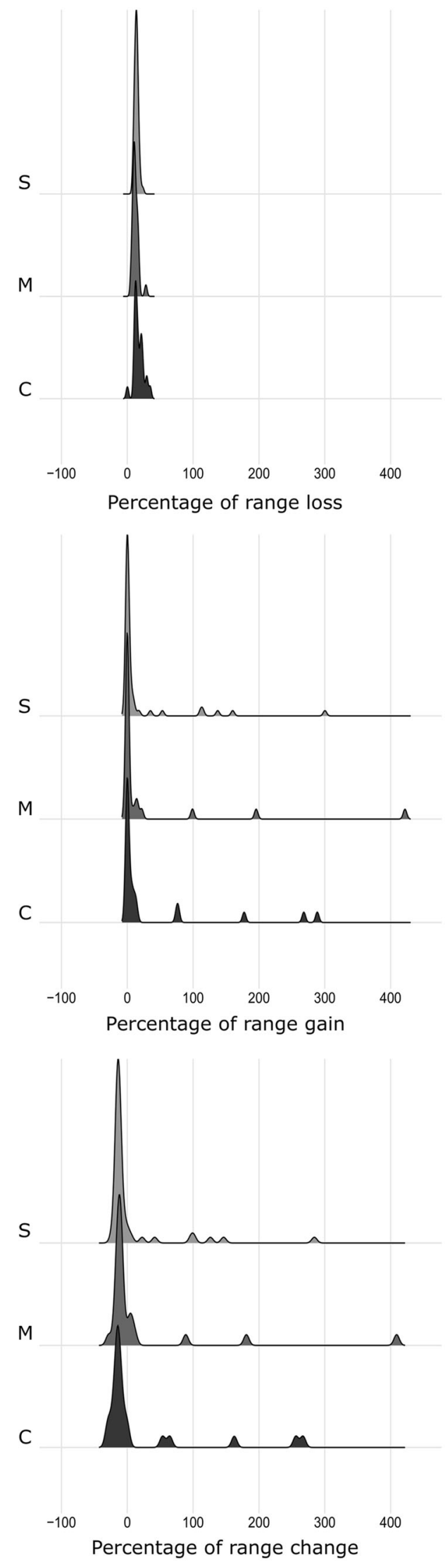

PESSIMISTIC SCENARIO (RCP8.5)

$\mathrm{S}$

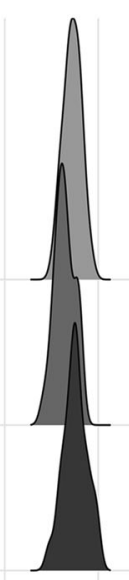

C

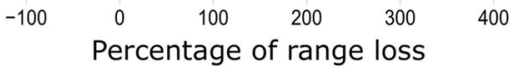

S

M

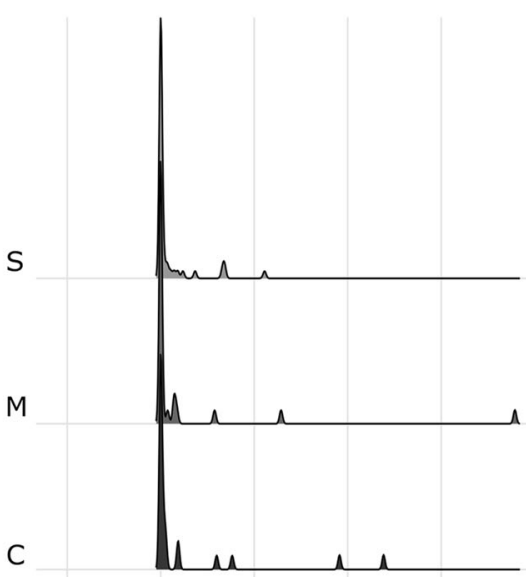

$\begin{array}{lllll}-100 & 0 & 100 & 200 & 300\end{array} 400$

Percentage of range gain

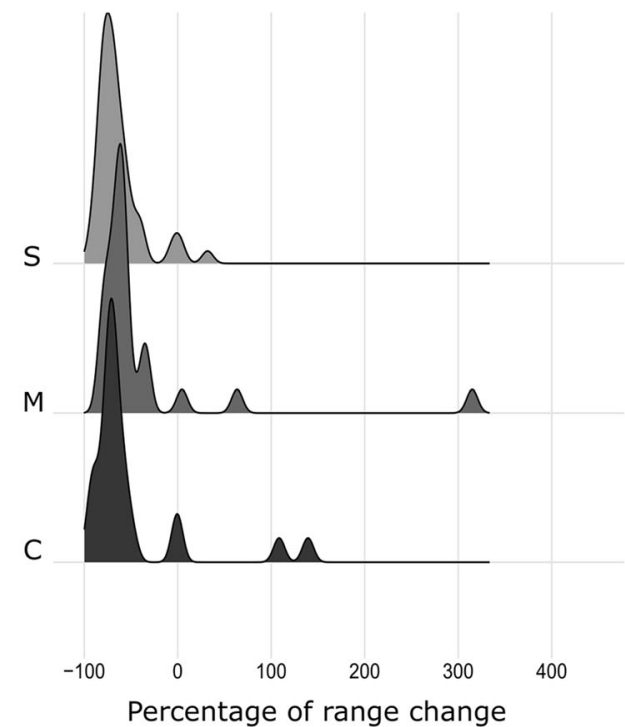



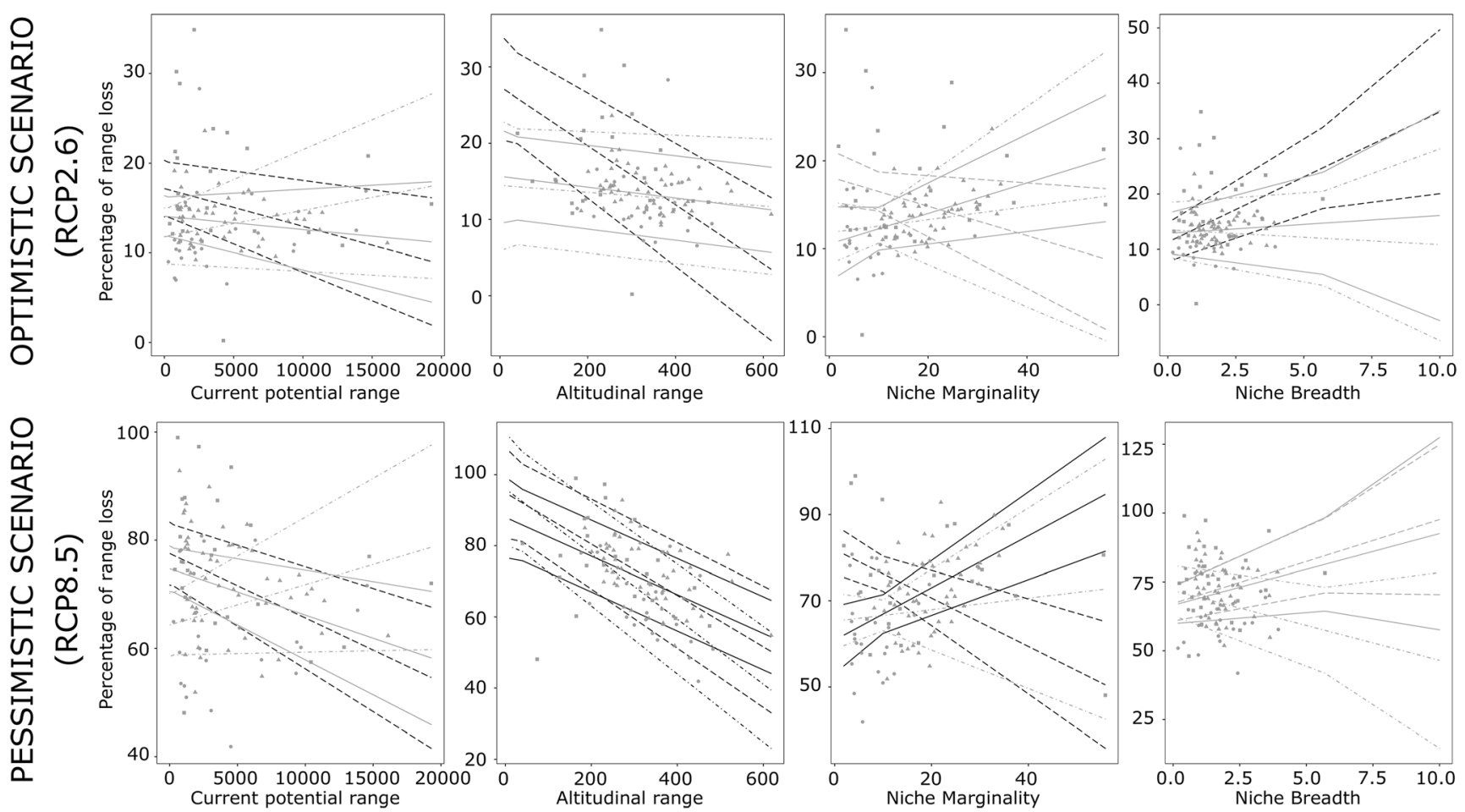

Fig. 3 Results of multiple regression analyses between range loss and predictors of range dynamics under optimistic (i.e. RCP 2.6) and pessimistic (i.e. RCP 8.5) scenarios for studied taxa belonging to each vegetation belt. Squares and dashed lines: colline; circles and dot-dashed

lines: montane; triangles and solid lines: subalpine. Black lines indicate a statistically significant correlation ( $p$ value $<0.05$ ); grey lines indicate a non-significant correlation ( $p$ value $>0.05$ )

The marked difference we detected between emission scenarios in the projected species distribution in 2070 (Fig. 2, Online Resource 5) is in line with previous studies (Loarie et al. 2008; Engler et al. 2011; Casazza et al. 2014). The small range contraction projected under the optimistic scenario (Fig. 2, Online Resource 5) supports the crucial role played by the reduction of $\mathrm{CO}_{2}$ emissions in the next decades to assure the overall conservation of biodiversity (Thomas et al. 2004). In
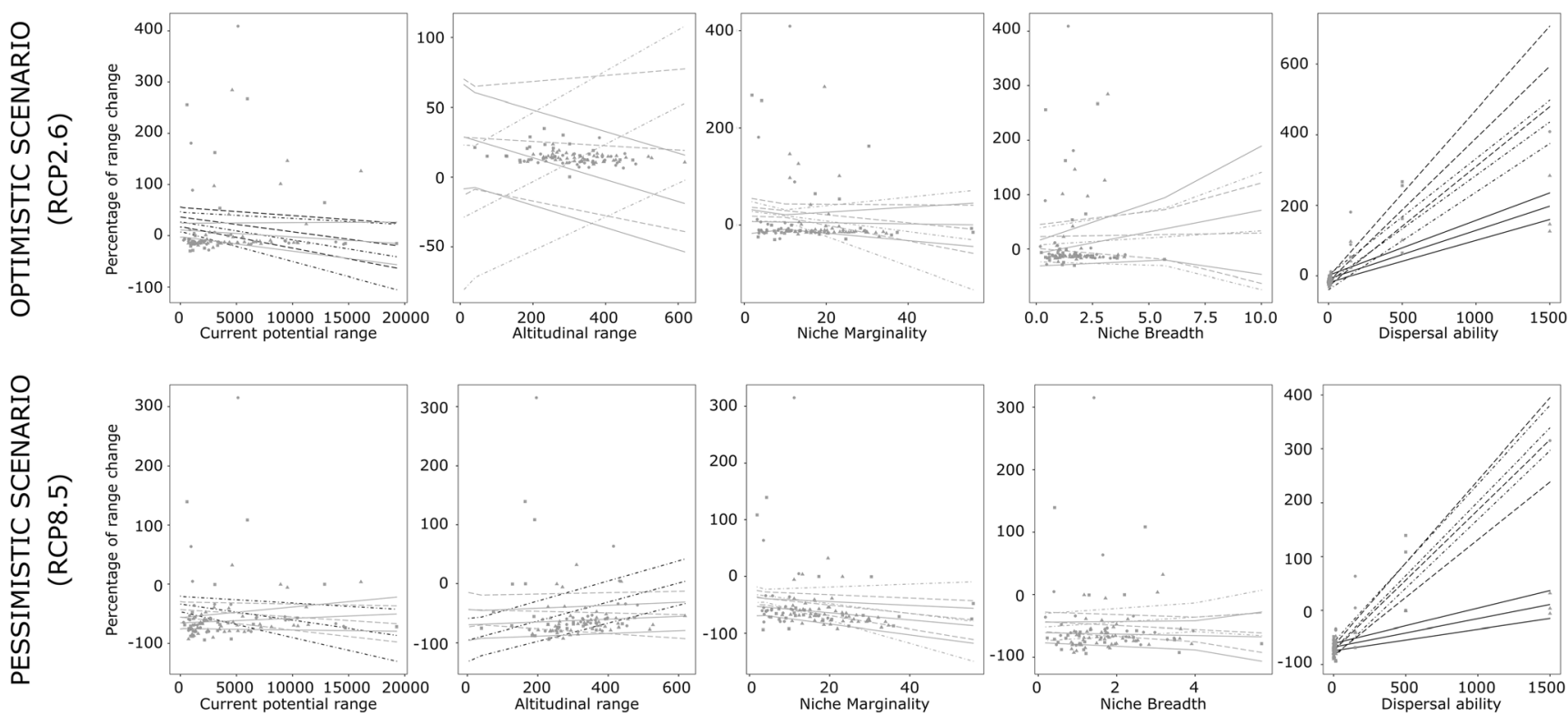

Fig. 4 Results of multiple regression analyses between range change and predictors of range dynamics under optimistic (i.e. RCP 2.6) and pessimistic (i.e. RCP 8.5) scenarios for studied taxa belonging to each vegetation belt. Squares and dashed lines: colline; circles and dot-dashed

lines: montane; triangles and solid lines: subalpine. Black lines indicate a statistically significant correlation ( $p$ value $<0.05$ ); grey lines indicate a non-significant correlation ( $p$ value $>0.05$ ) 
particular, the climate projected under this optimistic scenario is expected to fall within the climatic variability that species already experienced during the Holocene (Guiot and Cramer 2016; Fauquette et al. 2018) and therefore, strong range contractions will probably start after the 2070s (Engler et al. 2009). Consequently, the difference in range change we detected between the two scenarios may be partially due to the difference in the time of onset of climate change effect on species range, occurring earlier in the pessimistic than in the optimistic scenario.

Despite the projected changes in the potential range, only few species under the pessimistic scenario are exposed to high extinction risk (e.g. Epipactis leptochila (Godfery) Godfery subsp. provincialis (Aubenas \& Robatsch) J.M.Tison, Gentiana burseri Lapeyr. subsp. actinocalyx Polidori, Santolina decumbens Mill., Oreochloa seslerioides (All.) K.Richt.-Fig. 2, Online Resource 5). This result suggests that, although strong changes in distributional patterns of single species will occur, the endemic species in SW Alps are projected to be slightly affected by future climate change, albeit our approach does not take into account species extinction resulting from stochastic events. However, the strength of the climate change may delay or hasten the species extinction (Kuussaari et al. 2009), suggesting that the projected absence of extinctions under the optimistic scenario in SW Alps during the investigated time interval should not be interpreted as an absence of species extinction threat on a longer term. Due to the projected low risk of species extinction, the results for the SW Alps contrast with previous studies on European mountain systems (Engler et al. 2011; Thuiller et al. 2005a). By using a coarse spatial resolution and truncated niche space, they probably did not detect local microrefugia, resulting in an overestimation of the species extinction rate (Randin et al. 2009). In fact, microclimatic heterogeneity may reduce extinction risk from anthropogenic warming (Sugitt et al. 2018 but see Trivedi et al. 2008 for a contrary opinion). Otherwise, the projected low extinction of endemic species is in line with the expectation that rough topography and microclimatic diversity will likely buffer the effects of climate change and species extinction in centres of endemism, as it already took place in the past (Harrison and Noss 2017). In particular, the high regional and local environmental heterogeneities of the SW Alps buffered the effect of past climate changes, both reducing the species extinctions and promoting the current endemism richness of the region (Médail and Diadema 2009; Casazza et al. 2016).

\section{Differences in range change between vegetation belts}

The variation in distribution range is higher in endemics occurring at low and high altitude, while species belonging to montane vegetation belt are less threatened by climate change. In particular, $16 \%$ of colline, $3.8 \%$ of mountain and $18.3 \%$ of subalpine species are projected to lose more than $80 \%$ of their suitable habitat under the pessimistic scenario (Fig. 2, Online Resource 5). In the SW Alps, several mountain species occur under a climate with large seasonal variations (i.e. meso-Mediterranean climate, characterized by hot and arid summer and cold winter), consequently the future climatic conditions will probably lie within those the species already experience at least in some periods of the year (Thuiller et al. 2005b; Thuiller et al. 2006; Tielbörger et al. 2014). Moreover, the overall low impact of climate change detected for mountain species is likely favoured by the wide altitudinal range of the majority of them. In fact, in these species the upward shift of climate will enable the majority of populations to remain within the climatic conditions experienced by populations at the lower altitudes. These features may explain the low impact of climate change projected for the species belonging to this vegetation belt.

Conversely, the high range contraction detected in colline species contrasts with the general expectation according to which low elevation species are less sensitive to climate change because they have more opportunities to shift their range upward (Lenoir et al. 2008; Benito et al. 2011; Chen et al. 2011; Engler et al. 2011). Nevertheless, high range contraction was previously detected for several colline species growing in north Mediterranean coasts (Casazza et al. 2014). The high range contraction detected in colline endemics of the SW Alps supports the idea that the lower the range limits and optima were situated historically, the faster they are expected to shift upwards (Rumpf et al. 2018). In fact, taking into account their low dispersal ability, several of colline endemics might not be able to migrate fast enough to keep pace with climate change.

The highest contraction of distributional range detected in subalpine species was previously detected in other studies that suggested a high sensitivity to climate change in high elevation species (Engler et al. 2011; Gottfried et al. 2012). Overall, the weaker impact of climate change on the mountain than on colline and subalpine species is in line with the idea that the repeated up- and downshifts of the bioclimatic belts during past climatic fluctuations eliminated the lower and higher altitude species favouring mainly the persistence of mid-altitude species (Prodon et al. 2002).

\section{The effect of niche properties on range loss and change}

Similarly to vegetation belts where species occur, distribution range and niche properties are expected to strongly affect plants response to climate change because they are related to the degree of ecological specialization of species (Thuiller et al. 2005a; Thuiller et al. 2005b; Broennimann et al. 2006; Clavel et al. 2011; Casazza et al. 2014). Our projections are partially in line with the general expectation that species with 
narrow ranges are affected more strongly by climate change than species with wider ranges because they have narrow niches (Lawton and May 1995; Gaston 1998; Thuiller et al. 2005b; Essl et al. 2009). In particular, we found that the present range and altitudinal range, which measure the spatial extent of suitable conditions for a species, are negatively related to RL under the pessimistic scenario (Fig. 3; Online Resource 6). Moreover, the present range is also negatively associated with RC (Fig. 4; Online Resource 6). Species with the narrowest distributional ranges are further threatened by climate change because generally they would have to strongly shift their distributional range to keep pace with change, albeit they usually have the lowest dispersal ability (Schwartz et al. 2006). Conversely, species having a wide geographic distribution are likely to have also a broad niche because they occur under a variety of environmental conditions; consequently, they are expected to be less sensitive to future climate change (Thuiller et al. 2005b; Clavel et al. 2011). Nevertheless, contrary to this general expectation, niche breadth was never negatively related to RL and to RC. Differently, niche marginality was significantly positively associated with RL in subalpine species and it was significantly negatively related to RL in colline species (Fig. 3; Online Resource 6). Because niche marginality is a proxy for the climatic specialization of a species in relation to the mean climatic conditions of the region where it occurs, our results suggest that specialist species growing under warm and arid conditions (i.e. steno-Mediterranean species in the colline belt) are projected to lose less range by climate change than orophytes growing under cold and wet conditions (i.e. subalpine species sensu stricto). In fact, in the subalpine belt, the lowest values of RL were found in species growing under temperate climate, close to the mean climatic conditions of the study area (i.e. generalist species with ecological affinities with mountain species). All these findings suggest that the relationship between plants' sensitivity to climate change and both niche properties and vegetation belts is affected by the difference between the current climate where species grow and the projected climate, rather than the simply measure of climatic tolerance of the species. The strong positive relationship between dispersal abilities and range change detected in both scenarios (i.e. the higher the dispersion ability, the smaller the impact of climate change-Fig. 4, Online Resource 6) is in line with the expectation that the distribution of endemic plants may be strongly affected by their dispersal limitation (Essl et al. 2011). Moreover, this result supports the idea that species with poor dispersal ability are less able to keep pace with changes in their suitable environments (Malcolm et al. 2002; Jiménez-Alfaro et al. 2016) and therefore more prone to range reduction (Ozinga et al. 2009). Consequently, assisted colonization (i.e. the human-facilitated migration) should be considered to assure survival of endemic species under future climate (IUCN (International Union for Conservation of
Nature) SSC (Species Survival Commission) 2013). Eventually, our results suggest that niche properties mainly affect the likelihood of species to persist in situ (i.e. RL) while dispersal ability mainly affects the possibility of species to track the shift in suitable areas (i.e. RC).

\section{Conclusion}

Taken together, our results suggest that, in line with the expectation of biogeographical processes linked to a centre of endemism (Harrison and Noss 2017), the rough topography and ecological heterogeneity of the SW Alps will probably buffer endemic plants against future climate change. Nevertheless, the strength of the buffering strongly depends on the capability to maintain climate change within the limits already experienced by species during the Holocene (Fauquette et al. 2018). Furthermore, the low number of species projected to be at risk of extinction in the next decades in the SW Alps differs from the general trend detected for the other European mountain systems (Engler et al. 2011; Thuiller et al. 2005a). This difference may be because of the presence of a Mediterranean flora which seems to be less affected by climate change than the alpine one and the ability of fine-scale analysis to take into account the local persistence of species, fundamental for the survival of endemics. Moreover, the response of SW Alps endemics to climate change largely depends on the difference between the current climate where species grow and the future climate. Therefore, to explore the effects of past climate changes on the distribution of species endemic to Mediterranean mountains might allow us to detect putative future refugia that will be disproportionately important for conservation purposes, as they will likely be islands of high climatic stability and low competition increase for most endemics.

Funding Open access funding provided by Università degli Studi di Genova within the CRUI-CARE Agreement. This research was carried out under the project BIODIVAM (Biodiversity of Mediterranean Alps) of the Operational Programme Italy-France ALCOTRA 2007-2013. DD was supported by a $\mathrm{PhD}$ scholarship provided by the University of Genoa. GC gratefully acknowledges financial support from the European Union's Horizon 2020 research and innovation programme under grant agreement no 793226.

\section{Compliance with ethical standards}

Conflict of interest The authors declare that they have no conflict of interest.

Open Access This article is licensed under a Creative Commons Attribution 4.0 International License, which permits use, sharing, adaptation, distribution and reproduction in any medium or format, as long as you give appropriate credit to the original author(s) and the source, provide a link to the Creative Commons licence, and indicate if changes were made. The images or other third party material in this article 
are included in the article's Creative Commons licence, unless indicated otherwise in a credit line to the material. If material is not included in the article's Creative Commons licence and your intended use is not permitted by statutory regulation or exceeds the permitted use, you will need to obtain permission directly from the copyright holder. To view a copy of this licence, visit http://creativecommons.org/licenses/by/4.0/.

\section{References}

Aeschimann D, Rasolofo N, Theurillat JP (2011) Analyse de la flore des Alpes. 2: biodiversité et chorologie. Candollea 66(2):225-253. https://doi.org/10.15553/c2011v661a2

Allouche O, Tsoar A, Kadmon R (2006) Assessing the accuracy of species distribution models: prevalence, kappa and the true skill statistic (TSS). J Appl Ecol 43:1223-1232. https://doi.org/10.1111/j.13652664.2006.01214.x

Araújo MB, New M (2007) Ensemble forecasting of species distributions. Trends Ecol Evol 22:42-47. https://doi.org/10.1016/j.tree. 2006.09.010

Barbet-Massin M, Jiguet F, Albert CH, Thuiller W (2012) Selecting pseudo-absences for species distribution models: how, where and how many? Methods Ecol Evol 3:327-338. https://doi.org/10.1111/ j.2041-210X.2011.00172.x

Bellard C, Bertelsmeier C, Leadley P, Thuiller W, Courchamp F (2012) Impacts of climate change on the future of biodiversity. Ecol Lett 15: 365-377. https://doi.org/10.1111/j.1461-0248.2011.01736.x

Benito B, Lorite J, Peñas J (2011) Simulating potential effects of climatic warming on altitudinal patterns of key species in Mediterraneanalpine ecosystems. Clim Chang 108:471-483. https://doi.org/10. 1007/s10584-010-0015-3

Breiman L (2001) Random forests. Mach Learn 45:5-32. https://doi.org/ 10.1023/A:1010933404324

Breiman L, Friedman J, Ohlsen R, Stone C (1984) Classification and regression trees. Wadsworth International Group, New York

Broennimann O, Thuiller W, Hughes G, Midgley GF, Alkemade JMR, Guisan A (2006) Do geographic distribution, niche property and life form explain plants' vulnerability to global change? Glob Chang Biol 12:1079-1093. https://doi.org/10.1111/j.1365-2486.2006. 01157.x

Cahill AE, Aiello-Lammens ME, Fisher-Reid MC, Hua X, Karanewsky CJ, Yeong Ryu H, et al (2012) How does climate change cause extinction? Proc R Soc Lond B Biol Sci:rspb20121890. https://doi. org/10.1098/rspb.2012.1890

Cao Y, DeWalt RE, Robinson JL, Tweddale T, Hinz L, Pessino M (2013) Using Maxent to model the historic distributions of stonefly species in Illinois streams: the effects of regularization and threshold selections. Ecol Model 259:30-39. https://doi.org/10.1016/j.ecolmodel. 2013.03.012

Casazza G, Barberis G, Minuto L (2005) Ecological characteristics and rarity of endemic plants of the Italian Maritime Alps. Biol Conserv 123:361-371. https://doi.org/10.1016/j.biocon.2004.12.005

Casazza G, Zappa E, Mariotti MG, Médail F, Minuto L (2008) Ecological and historical factors affecting distribution pattern and richness of endemic plant species: the case of the Maritime and Ligurian Alps hotspot. Divers Distrib 14:47-58. https://doi.org/10.1111/j.14724642.2007.00412.x

Casazza G, Giordani P, Benesperi R, Foggi B, Viciani D, Filigheddu R, Mariotti MG (2014) Climate change hastens the urgency of conservation for range-restricted plant species in the Central-Northern Mediterranean region. Biol Conserv 179:129-138. https://doi.org/ 10.1016/j.biocon.2014.09.015
Casazza G, Grassi F, Zecca G, Minuto L (2016) Phylogeographic insights into a peripheral refugium: the importance of cumulative effect of glaciation on the genetic structure of two endemic plants. PLoS One 11:e0166983. https://doi.org/10.1371/journal.pone.0166983

Chen IC, Hill LJK, Ohlemüller R, Roy DB, Thomas CD (2011) Rapid range shifts of species associated with high levels of climate warming. Science 333(6045):1024-1026. https://doi.org/10.1126/ science. 1206432

Clavel J, Julliard R, Devictor V (2011) Worldwide decline of specialist species: toward a global functional homogenization? Front Ecol Environ 9:222-228. https://doi.org/10.1890/080216

Cotto O, Wessely J, Georges D, Klonner G, Schmi M, Dullinger S, Thuiller W, Guillaume F (2017) A dynamic eco-evolutionary model predicts slow response of alpine plants to climate warming. Nat Commun 8:15399. https://doi.org/10.1038/ncomms15399

Dirnböck T, Essl F, Rabitsch W (2011) Disproportional risk for habitat loss of high-altitude endemic species under climate change. Glob Chang Biol 17:990-996. https://doi.org/10.1111/j.1365-2486.2010. 02266.x

Dolédec S, Chessel D, Gimaret-Carpentier C (2000) Niche separation in community analysis: a new method. Ecology 81:2914-2927. https:// doi.org/10.1890/0012-9658(2000)081[2914:NSICAA]2.0.CO;2

Dray S, Dufour AB (2007) The ade4 package: implementing the duality diagram for ecologists. J Stat Softw 22(4):1-20. https://doi.org/10. 18637/jss.v022.i04

Dullinger S, Gattringer A, Thuiller W, Moser D, Zimmermann NE, Guisan A, et al (2012) Extinction debt of high-mountain plants under twenty-first-century climate change. Nat Clim Chang 2: 619-622. https://doi.org/10.1038/nclimate1514

Engler R, Randin CF, Vittoz P, Czáka T, Beniston M, Zimmermann NE, Guisan A (2009) Predicting future distributions of mountain plants under climate change: does dispersal capacity matter? Ecography 32:34-45. https://doi.org/10.1111/j.1600-0587.2009.05789.x

Engler R, Randin CF, Thuiller W, Dullinger S, Zimmermann NE, Araújo MB, Pearman PB, Le Lay G, Piedallu C, Albert CH, Choler P, et al (2011) 21st century climate change threatens mountain flora unequally across Europe. Glob Chang Biol 17:2330-2341. https:// doi.org/10.1111/j.1365-2486.2010.02393.x

Essl F, Staudinger M, Stöhr O, Schratt-Ehrendorfer L, Rabitsch W, Niklfeld H (2009) Distribution patterns, range size and niche breadth of Austrian endemic plants. Biol Conserv 142(11):2547-2558. https://doi.org/10.1016/j.biocon.2009.05.027

Essl F, Dullinger S, Plutzar C, Willner W, Rabitsch W (2011) Imprints of glacial history and current environment on correlations between endemic plant and invertebrate species richness. J Biogeogr 38: 604-614. https://doi.org/10.1111/j.1365-2699.2010.02425.x

Fauquette S, Suc J-P, Médail F, Muller SD, Jiménez-Moreno G, et al (2018) The Alps: a geological, climatic, and human perspective on vegetation history and modern plant diversity. In: Hoorn C, Perrigo A, Antonelli A (eds) Mountains, climate, and biodiversity. Wiley ed, Oxford, pp 413-428

Freeman EA, Moisen G (2008) PresenceAbsence: an R package for presence-absence model analysis. J Stat Softw 23(11):1-31. http:// www.jstatsoft.org/v23/i11. https://doi.org/10.18637/jss.v023.i11

Friedman JH (1991) Multivariate adaptive regression splines. Ann Stat 19:1-67. https://doi.org/10.1214/aos/1176347973

Gaston KJ (1998) Species-range size distributions: products of speciation, extinction and transformation. Philos Trans R Soc Lond B 353:219 230. https://doi.org/10.1098/rstb.1998.0204

Gottfried M, Pauli H, Futschik A, Akhalkatsi M, Barančok P, Benito Alonso JL, et al (2012) Continent-wide response of mountain vegetation to climate change. Nat Clim Chang 2:111-115. https://doi. org/10.1038/nclimate1329

Guiot J, Cramer W (2016) Climate change: the 2015 Paris Agreement thresholds and Mediterranean basin ecosystems. Science 354(6311): 465-468. https://doi.org/10.1126/science.aah5015 
Guisan A, Zimmermann NE (2000) Predictive habitat distribution models in ecology. Ecol Model 135:147-186. https://doi.org/10.1016/ S0304-3800(00)00354-9

Hamann A, Roberts DR, Barber QE, Carrol C, Nielsen SE (2015) Velocity of climate change algorithms for guiding conservation and management. Glob Chang Biol 21:997-1004. https://doi.org/ 10.1111/gcb.12736

Hanley JA, McNeil BJ (1982) The meaning and use of the area under a receiver operating characteristic (ROC) curve. Radiology 143:29 36. https://doi.org/10.1148/radiology.143.1.7063747

Harrison S, Noss R (2017) Endemism hotspots are linked to stable climatic refugia. Ann Bot 119:207-214. https://doi.org/10.1093/aob/ mew248

Hijmans RJ, Phillips S, Leathwick J, Elith J (2017) dismo: species distribution modeling. R package version 1.1-4. https://CRAN.R-project. org $/$ package $=$ dismo

Hoorn C, Perrigo A, Antonelli A (eds) (2018) Mountains, climate and biodiversity. Wiley Blackwell, Oxford

Huss M, Bookhagen B, Huggel C, Jacobsen D, Bradley RS, Clague JJ, et al (2017) Toward mountains without permanent snow and ice. Earth's Future 5:418-435. https://doi.org/10.1002/2016EF000514

IUCN (International Union for Conservation of Nature) SSC (Species Survival Commission) (2013) IUCN guidelines for reintroductions and other conservation translocations. IUCN SSC, Gland

Jiménez-Alfaro B, García-Calvo L, García P, Acebes JL (2016) Anticipating extinctions of glacial relict populations in mountain refugia. Biol Conserv 201:243-251. https://doi.org/10.1016/j. biocon.2016.07.015

Karger DN, Conrad O, Böhner J, Kawohl T, Kreft H, Soria-Auza RW, et al (2017a) Climatologies at high resolution for the earth's land surface areas. Scientific Data 4:170122. https://doi.org/10.1038/ sdata.2017.122

Karger DN, Conrad O, Böhner J, Kawohl T, Kreft H, Soria-Auza RW, Zimmermann NE, Linder HP, Kessler M (2017b) Data from: climatologies at high resolution for the earth's land surface areas. Dryad Digital Repository. https://doi.org/10.5061/dryad.kd1d4

Kuussaari M, Bommarco R, Heikkinen RK, Helm A, Krauss J, Lindborg R, Öckinger E, Pärtel M, Pino J, Rodà F, Stefanescu C, Teder T, Zobel M, Steffan-Dewenter I (2009) Extinction debt: a challenge for biodiversity conservation. Trends Ecol Evol 24:564-571. https:// doi.org/10.1016/j.tree.2009.04.011

Lawton JH, May RM (1995) Extinction rates. Oxford Univ. Press, Oxford

Lenoir J, Gégout JC, Marquet PA, de Ruffray P, Brisse H (2008) A significant upward shift in plant species optimum elevation during the $20^{\text {th }}$ century. Science 320(5884):1768-1771. https://doi.org/10. 1126/science.1156831

Liu C, Berry PM, Dawson TP, Pearson RG (2005) Selecting thresholds of occurrence in the prediction of species distributions. Ecography 28: 385-393. https://doi.org/10.1111/j.0906-7590.2005.03957.x

Loarie SR, Carter BE, Hayhoe K, McMahon S, Moe R, Knight CA, Ackerly DD (2008) Climate change and the future of California's endemic flora. PLoS One 3:e2502. https://doi.org/10.1371/journal. pone.0002502

Loarie SR, Duffy PB, Hamilton H, Asner GP, Field CB, Ackerly DD (2009) The velocity of climate change. Nature 462:1052-1057. https://doi.org/10.1038/nature08649

Maiorano L, Cheddadi R, Zimmermann NE, Pellissier L, Petitpierre B, et al (2012) Building the niche through time: using 13,000 years of data to predict the effects of climate change on three tree species in Europe. Global Ecol Biogeogr Special Issue. https://doi.org/10. $1111 /$ j.1466-8238.2012.00767.x

Malcolm JR, Markham A, Neilson RP, Garaci M (2002) Estimated migration rates under scenarios of global climate change. J Biogeogr 29:835-849. https://doi.org/10.1046/j.1365-2699.2002.00702.x
Marazzi S (2005) Atlante orografico delle Alpi: SOIUSA: suddivisione orografica internazionale unificata del sistema alpino. Priuli \& Verlucca ed., Pavone Canadese (TO), Italy

Marmion M, Parviainen M, Luoto M, Heikkinen RK, Thuiller W (2009) Evaluation of consensus methods in predictive species distribution modelling. Divers Distrib 15(1):59-69. https://doi.org/10.1111/j. 1472-4642.2008.00491.x

McCullagh P, Nelder JA (1989) Generalized linear models. CRC Press, London

Médail F, Diadema K (2009) Glacial refugia influence plant diversity patterns in the Mediterranean Basin. J Biogeogr 36:1333-1345. https://doi.org/10.1111/j.1365-2699.2008.02051.x

Médail F, Quézel P (1997) Hot-spots analysis for conservation of plant biodiversity in the Mediterranean basin. Ann Mo Bot Gard 84:112127. https://doi.org/10.2307/2399957

Moritz C, Agudo R (2013) The future of species under climate change: resilience or decline? Science 341:504-508. https://doi.org/10.1126/ science. 1237190

Nogués-Bravo D, Araújo MB, Errea MP, Martínez-Rica JP (2007) Exposure of global mountain systems to climate warming during the 21st century. Glob Environ Chang 17:420-428. https://doi.org/ 10.1016/j.gloenvcha.2006.11.007

Ozinga WA, Römermann C, Bekker RM, Prinzing A, Tamis WLM, Schaminée JHJ, et al (2009) Dispersal failure contributes to plant losses in NW Europe. Ecol Lett 12:66-74. https://doi.org/10.1111/j. 1461-0248.2008.01261.x

Parmesan C, Duarte C, Poloczanska E, Richardson AJ, Singer MC (2011) Overstretching attribution. Nat Clim Chang 1:2-4. https://doi.org/ 10.1038 /nclimate 1056

Pauli H, Gottfried M, Dullinger S, Abdaladze O, Akhalkatsi M, et al (2012) Recent plant diversity changes on Europe's mountain summits. Science 336:353-355. https://doi.org/10.1126/science. 1219033

Pereira HM, Leadley PW, Proença V, Alkemade R, Scharlemann JPW, et al (2010) Scenarios for global biodiversity in the 21st century. Science 330:1496-1501. https://doi.org/10.1126/science.1196624

Petchey OL, Pontarp M, Massie TM, Kéfi S, Ozgul A, Weilenmann M, et al (2015) The ecological forecast horizon, and examples of its uses and determinants. Ecol Lett 18:597-611. https://doi.org/10.1111/ ele. 12443

Petitpierre B, Broennimann O, Kueffer C, Daehler C, Guisan A (2017) Selecting predictors to maximize the transferability of species distribution models: lessons from cross-continental plant invasions. Glob Ecol Biogeogr 26:275-287. https://doi.org/10.1111/geb.12530

Prodon R, Thibault JC, Dejaifve PA (2002) Expansion vs. compression of bird altitudinal ranges on a Mediterranean island. Ecology 83(5): 1294-1306. https://doi.org/10.1890/0012-9658(2002)083[1294: EVCOBA]2.0.CO;2

R Core Team (2017) R: a language and environment for statistical computing. R Foundation for statistical computing, Vienna. URL https:// www.R-project.org/

Randin CF, Engler R, Normand S, Zappa M, Zimmermann NE, Pearman PB, Vittoz P, Thuiller W, Guisan A (2009) Climate change and plant distribution: local models predict high-elevation persistence. Glob Chang Biol 15:1557-1569. https://doi.org/10.1111/j.1365-2486. 2008.01766.x

Ridgeway G (1999) The state of boosting. Stat Comput 31:172-181

Rumpf SB, Hülber K, Klonner G, Moser D, Schütz M, Wessely J, Willner W, Zimmermann NE, Dullinger S (2018) Range dynamics of mountain plants decrease with elevation. PNAS 115(8):1848 1853. https://doi.org/10.1073/pnas.1713936115

Sandel B, Arge L, Dalsgaard B, Davies RG, Gaston KJ, Sutherland WJ, Svenning JC (2011) The influence of Late Quaternary climate change velocity on species endemism. Science 334:660-664. https://doi.org/10.1126/science.1210173 
Sanderson BM, Knutti R, Caldwell P (2015) A representative democracy to reduce interdependency in a multimodel ensemble. J Clim 28: 5171-5194. https://doi.org/10.1175/JCLI-D-14-00362.1

Sax DF, Early R, Bellemare J (2013) Niche syndromes, species extinction risks, and management under climate change. Trends Ecol Evol 28: 517-523. https://doi.org/10.1016/j.tree.2013.05.010

Schwartz MW, Iverson LR, Prasad AM, Matthews SN, O'Connor RJ (2006) Predicting extinctions as a result of climate change. Ecology 87(7):1611-1615. https://doi.org/10.1890/00129658(2006)87[1611:PEAARO]2.0.CO;2

Sugitt AJ, Wilson RJ, Isaac NJB, Beale CM, Auffret AG, et al (2018) Extinction risk from climate change is reduced by microclimatic buffering. Nat Clim Chang 8:713-717. https://doi.org/10.1038/s41558018-0231-9

Thomas CD, Cameron A, Green RE, Bakkenes M, Beaumont LJ, et al (2004) Extinction risk from climate change. Nature 427:145-148. https://doi.org/10.1038/nature02121

Thuiller W, Lavorel S, Araújo MB, Sykes MT, Prentice IC (2005a) Climate change threats to plant diversity in Europe. Proc Natl Acad Sci U S A 102:8245-8250. https://doi.org/10.1073/pnas. 0409902102

Thuiller W, Lavorel S, Araújo MB (2005b) Niche properties and geographical extent as predictors of species sensitivity to climate change. Glob Ecol Biogeogr 14:347-357. https://doi.org/10.1111/ j.1466-822X.2005.00162.x

Thuiller W, Midgley GF, Hughes GO, Bomhard B, Drew G, Rutherford MC, Woodward FI (2006) Endemic species and ecosystem sensitivity to climate change in Namibia. Glob Chang Biol 12: 759-776. https://doi.org/10.1111/j.1365-2486.2006.01140.x

Thuiller W, Lafourcade B, Engler R, Araújo MB (2009) BIOMOD - a platform for ensemble forecasting of species distributions. Ecography 32:369-373. https://doi.org/10.1111/j.1600-0587.2008. 05742. $\mathrm{x}$

Tielbörger K, Bilton MC, Metz J, Kigel J, Holzapfel C, et al (2014) Middle-Eastern plant communities tolerate 9 years of drought in a multi-site climate manipulation experiment. Nat Commun 5:5102. https://doi.org/10.1038/ncomms6102

Trivedi MR, Berry PM, Morecroft MD, Dawson TP (2008) Spatial scale affects bioclimate model projections of climate change impacts on mountain plants. Glob Chang Biol 14:1089-1103. https://doi.org/ 10.1111/j.1365-2486.2008.01553.x

van Proosdij ASJ, Sosef MSM, Wieringa JJ, Raes N (2016) Minimum required number of specimen records to develop accurate species distribution models. Ecography 39:542-552. https://doi.org/10. 1111/ecog.01509

Vittoz P, Engler R (2007) Seed dispersal distances: a typology based on dispersal modes and plant traits. Bot Helv 117:109-124. https://doi. org/10.1007/s00035-007-0797-8

Publisher's note Springer Nature remains neutral with regard to jurisdictional claims in published maps and institutional affiliations. 